\title{
The cultural and political ecology of reed-cane craftsmanship in Lake Eber
}

\author{
Evren Ekiz $^{1 *}$, Hakki Yazici ${ }^{1}$ \\ ${ }^{1}$ Afyon Kocatepe University, Turkey
}

The current study examines the interactions of people living around Lake Eber with the lake and their use of it from a cultural and political ecology perspective. In this context, fieldworks were carried out in different periods of 2018-2019. At the same time, observations and interviews covering the research subject were carried out. In the study, it was determined that aquatic plants such as common reed, reedmace, lakeshore bulrush and common cattail are cut from the Lake Eber and are used as building materials and in the production of rush mats, beach umbrellas, prayer rugs, reed pillows, floor mats (straw) and tomb mats. On the other hand, it was observed that the interest in reed-cane craftsmanship and the production of reed-cane products is decreasing every year. This is caused by drought, pollution and eutrophication processes seen in the lake. Based on the results of the study, we suggest that more field studies should be done to examine the factors that threaten the lake ecology and projects should be conducted to improve the situation in the lake.

Key Words: reed-cane craftsmanship, cultural ecology, political ecology, wetlands, Lake Eber.

Article Info: Received: July 20, 2020; Revised: February 10, 2021; Accepted: April 15, 2021; Online: May 31, 2021.

\footnotetext{
"Corresponding author

Address: Faculty of Education, Afyon Kocatepe University, Gazlıgöl Road, 03200, Afyonkarahisar, Turkey.

Phone: +902722181702 | Email: eekiz@aku.edu.tr
}

(C)2021 Human Geographies; The authors

(C) $\mathrm{C}$ This work is licensed under a

Creative Commons Attribution 4.0 International License. DOI:10.5719/hgeo.2021.151.2 


\section{Introduction}

Wetlands are home to migratory birds, various mammals, reptiles, terrestrial and aquatic creatures and various fish species. They are an indispensable element of wildlife and make important contributions to supporting ecological diversity and nutrition network, increasing water quality, regulating the water regime, and and balancing the local climate. In addition, it provides opportunities for various economic activities with its features allowing fishing, water supply, transportation, animal husbandry, hunting, reed-cane cutting and recreational activities (bird watching, water sports, camping, photography, accommodation) (Mitsch \& Gosselink, 2015; Arı, 2006; Güney, 1995; Korkmaz \& Gürbüz, 2008). Despite all these characteristics, wetlands have been seen for many years as the source of diseases and areas that needed to be dried. Predominantly until the 1960s, wetland management consisted of drying them. After the 1960s, the approach towards wetlands began to change. As such, the discovery of the contribution of wetlands to the protection of water quality and the prevention of floods led to initiatives to protect these areas.

In the $1990 \mathrm{~s}$, it was understood that wetlands were one of the habitats of humans for a long time; people benefited from these areas in various ways and were economically dependent on them and became a part of the wetland ecosystem with the mutual interaction they established (Arı, 2006). Wetlands, where human-environment interaction is experienced intensely, are affected by economic conditions, political decisions and socio-cultural values that develop and change over time (Hasbek, 2018). That is, a political decision taken for the protection of wetlands may limit the use of the wetland by local people. On the other hand, intensive use of wetlands by local people due to economic concerns can cause ecological deterioration. The decisions taken during the management of wetlands can affect, positively or negatively, the local people from these areas.

There are various studies in the international literature in which cultural and political ecology approaches are used to understand and reveal these and similar situations. In these studies, it is proved that the use, protection, management, political ecology of wetlands, relations between different stakeholders and conflicts of interest are discussed (Nagabhatla, \& Sellamuttu, 2008; Campion \& Owusu-Boateng, 2013; Astelarra et al., 2017; King at al, 2019; Huque et al., 2020). International literature documents extensively reed plants and their cutting activities, the effects of reed cutting/harvesting activities on wetland ecology (Decleer, 1990; Graveland, 1999; Poulin \& Lefebvre, 2002; Schmidt et al., 2005; Poulin et al., 2009; Trnka et al., 2014; Deak et al., 2015; Barbraud \& Mathevet, 2020). In addition, there are also studies focusing on the economic value of cutting/harvesting activities and its use as a bioenergy raw material (Mmopelwa, 2005; Komulainen et al., 2008; Van Der Sluis et al., 2013).

The first steps towards the protection of wetlands in Turkey were taken in the 1980s-90s. Turkey signed Ramsar Convention (a convention on wetlands of international importance, especially as waterfowl habitat) in 1994. The "Regulation on the Protection of Wetlands" was prepared and put into effect in 
2002 (Yeniyurt et al., 2011) in order to fulfil the obligations of the convention. Despite this, $85 \%$ of wetlands are negatively affected by human-induced developments. In this context, wetlands are confronted with threats such as irrigation and drainage projects, industrial and urban waste, illegal hunting, overgrazing and reed burning (Kandır, 2018).

A total of 14 Ramsar Sites, considered important on an international scale, 52 wetlands of national importance and 12 wetlands of local importance have been registered in Turkey. Studies on these areas started in the 1990s. Studies carried out in these years mostly focused on the physical structure of wetlands, the reasons for their drying and the drawbacks of their drying (Güney, 1995; Yiğitbașoğlu, 1995; Erdem, 1995; Yarar \& Magnin, 1997; Yazıcı \& Șahin, 1999). After Turkey became a signatory country to Ramsar Convention and "Regulation on the Protection of Wetlands" in 2001 was put into effect, studies on wetlands started to focus on the functions, values, problems, uses, protection and management of wetlands (Özeșmi, 1999; Arı, 2003; Arı, 2006; Adaman et al., 2006; Korkmaz \& Gürbüz, 2008; Arı \& Derinöz, 2011; Evered, 2012; Bahadır, 2012; Sönmez \& Somuncu, 2016; Korukoğlu et al., 2017; Hasbek \& Arı, 2018). Although there is not any study focusing totally on reed work or reed-reed cutting, it is possible to see that reed work or reed-reed cutting is mentioned in studies that include knitting and plant weaving (Türktas,, 2016; Kalkan \& Gönül, 2018; Türktaș, 2020).

Lake Eber, one of the wetlands of national importance, consists of marshes, reed fields and seasonal wetlands. These areas, which are very important in species diversity, contain 342 genera, 582 species and subspecies taxa belonging to 88 families. While pike (esox lucius), which has a limited water surface, was seen in the wetland in the past, today it has been replaced by carp (cyprinus carpio) due to water pollution, overfishing and the presence of other dominant species. Lake Eber, which is lacking in terms of fish diversity, is very rich in bird species. A total of 145 bird species have been observed in the studies conducted so far. The fact that the lake is on bird migration routes is effective in hosting so many bird species. Moreover, Lake Eber wetland offers a habitat for frog species, tortoise, spotted tortoise, lizard species, aquatic and semi-aquatic snake species. Coyotes, foxes, weasels, reed cats, various rodents and wild boars also constitute the mammal group living here (Kandır, 2018). With all these characteristics, the lake was registered as a $1^{\text {st }}$ degree natural site from 22.06.1992 until 03.11.2020 and as a "sensitive area to be strictly protected" on 03.11.2020 per Article 109 of the Presidential executive order numbered 1 (Ministry of Environment and Urbanisation, 2018).

Lake Eber offers various economic values to the settlements and local people around it with its ecological resources. The most prominent one was fishing which has lost its importance today. Pike, which provided an important economic return in the past years, is no longer present in the lake. As mentioned above, carp has taken the place of pike. However, with the increasing pollution, fishing in the lake and their consumption are not considered to be appropriate (Kandır, 2018). One of the sources with economic returns is reed-cane plants. Local people have cut 
plants that grow in the wetland and have economic value for many years. Another economic activity conducted in recent years is boat tours. These tours are primarily aimed at hunting various bird species found in the wetland.

The current study aims to examine the reed-cane craftsmanship and the reedcane products produced from Lake Eber, which allows various activities through its ecological resources from a cultural and political ecology perspective. In this context, the past and present of reed-cane craftsmanship, the usage of plants, the products obtained, and the developments and changes in the production have been studied.

\section{Methodology}

The current study employed the ethnography approach, one of the qualitative research methods thought to serve the purpose of the current study. An ethnographic research tries to understand the world and life through the eyes of those who live it (Geertz, 1983). This requires living in the culture that is studied. The best way to do this is through fieldwork. Ethnographic studies require comprehensive fieldwork (Hancock, 1998). In this context, the first daily fieldwork in Lake Eber and its surroundings was carried out on 10 February 2018. With this first fieldwork, the sample for the study was selected after obtaining information about Lake Eber and the settlements around it.

These are Ağılönü Neighbourhood / Bolvadin, Derekarabag village / Bolvadin, Ortakarabağ village / Bolvadin and Eber village / Çay. Factors such as reed-cane cutting and craftsmanship performed for long years, marketing of the plants domestically and abroad, production and marketing of various products from the cut plants with traditional and modern methods and their contribution to the family budget were influential in the selection of the mentioned settlements for the sample.

Subsequent fieldworks covered the months of July and November 2018 and March and August 2019, and a total of 6 fieldworks were carried out in a span of 2 years. The reason for selecting these months for the fieldworks is that reed-cane plants are intensely cut and marketed, and products from these plants are produced during these months. Daily fieldworks conducted in July and August were carried out to observe the interaction of the local people with the wetland while they were cutting reedmace and bulrush. At the same time, the authors had the opportunity to see the commercial activities of the cut plants. Fieldworks carried out in November provided the opportunity to see both the cutting of the cane and the production stage of the goods obtained from the plants. The daily fieldworks carried out in March provided the opportunity to see the stages of all products made out of reed-cane plants and workshops and marketing of the products. All of the fieldworks were carried out daily due to the close location of the lake to the city of Afyonkarahisar and its easy accessibility.

In most of the fieldworks, the people living in the settlements that constitute the sample area were contacted, and the knowledge, experience and opinions of 
the people about the wetland and the status of the wetland utilization were written down. Initially, contact was made with Mr. Ömer, who lives in the Ağılönü neighbourhood of Bolvadin district and is also a reed craftsman and involved in the commerce of reed products. Here it should be noted that all of the source persons who provided data during the research process are indicated with code names in the text. Later, six different people living in the settlements forming the sample area and engaged in reed-cane cutting, rush mate craftsmanship, reed pillow production and reed-cane trade were contacted.

From among these people, Mr. Ahmet and Mehmet work as masters of reed pillow, Mrs. Gülsüm is a master of floor mats, Mr. Ali and Hasan are reed-cane cutting workers and Mr. Osman is a master and trader of rush mats. In the selection of the aforementioned code names as resource persons, the following criteria were taken into account: they were born in the area, they have been doing the same job since their childhood, they earn income from these works, and they interact with Lake Eber.

During the fieldworks, the authors used the participant observation technique (Wilson, 1952), which is also called the ethnographic research technique or qualitative research method and in which the researcher is involved in the activities of the community observed by the researcher (Wilson, 1952), and the ethnographic interview technique that aims to explain the cultural structure of the community and the behaviours and experiences that make up this structure (Büyüköztürk et al., 2012).

The manner in which local people use the wetland and how local people interact with the area was determined through participatory observation. In this context, the researcher participated in reed-cane plants cutting together with Mr. Ali and Hasan in November and July and thus personally experienced the process. In February and March, the researcher participated in the production and marketing activities of reed-cane products and Mr. Mehmet and Ömer and Mrs. Gülsüm and exporting reed-cane products together with Mr. Osman in August. Thus, it was personally involved in the daily work of the local people. Notes were taken about the participated activities during the day and compiled at the end of the day. In addition, video recordings were taken with the permission of the participants and were converted into text at the end of the day.

Ethnographic interviews, on the other hand, were generally carried through open-ended questions during observation activities. This was done to know the local people better and to provide in-depth information flow for research. During the interviews, questions were asked about the reed-cane craftsmanship, the use of reed-cane plants, the products produced from reed-cane plants, the contribution of these products to the local economy and culture, and the changes in the ecological structure of Lake Eber. In this way, the views of the local people about the wetland and their state of being able to make use of the wetland were gathered. All the interviews were recorded instantly and compiled at the end of the day. Some of the data obtained from the interviews were included within the study as direct quotations. 
Although most of the data used in the study are qualitative data, quantitative data suitable for the subject and purpose were also used. Data about the development of the population in the settlements were obtained from the Turkish Statistical Institute (TSI), data about the pollution and the environmental problems were obtained from the Directorate of Environment and Urban Planning in the Afyonkarahisar Governor's Office and data about Lake Eber and the rivers feeding it were obtained from the General Directorate of State Hydraulic Works (SHW) and SHW $183^{\text {rd }}$ Branch Directorate of Afyonkarahisar.

Lake Eber, located within the borders of Afyonkarahisar province, is located in the Akarçay closed basin between the northwest slopes of the Sultan Mountains and the southern extensions of the Emirdag at an altitude of $965 \mathrm{~m}$ and has a tectonic origin in terms of formation (Atalay, 1977) (Figure 1).

Lake Eber is the first stop of Akarçay drainage system. Akarçay, the most important river of the basin, is named after the combination of Nacak Water that originates in Ahır Mountains and Gazlıgöl Stream near Gecek hot springs. From here, it flows into Lake Eber by forming meanders along the Afyonkarahisar Plain. It reaches Lake Akșehir through a stream from Lake Eber (Atalay, 1977). On the other hand, the natural flow was interrupted with the regulator built at the exit of Lake Eber in 1990 (Köle et al., 2016).

The lake area varies across the years, as it changes between 66 and $125 \mathrm{~km}^{2}$ (Atalay, 1977; SHW 183 ${ }^{\text {rd }}$ Branch Directorate of Afyonkarahisar, 2019). Depending on the amount of rainfall and the amount of water carried by the rivers, there are changes in the water level over the years. However, only onequarter of the lake area is water surface, and the rest consists of marshes covered by reeds and canes (Özdemir \& Günay, 2005) (Figure 1). According to the data obtained from the Turkish Statistical Institute (TSI) in 2019, the total number of people living in the settlements included in the sample is 34,189. Approximately $95 \%$ of this population is gathered in the district centre, and the remaining part is in three villages (Table 1).

The settlements in this area date back to the Primeval Age. As a matter of fact, the Hittite, Phrygian, Lydian, Persian, Roman and Byzantine dominations were experienced in Bolvadin and its surroundings. With the conquest of Anatolia by the Turks, the Oghuz Tribes settled in the area (Bayar, 1996). Derekarabağ and Ortakarabağ villages, which are also included in the sample area, were established in the $18^{\text {th }}$ century with people of the Karabakh Tribe, who migrated to Anatolia from the Ganja-Karabakh region of Azerbaijan (Eroğlu, 2009).

Table 1. Population Change in the Research Site Across the Census Years (TSI)

\begin{tabular}{lcccccccc}
\hline \multicolumn{1}{c}{ Settlement } & 1965 & 1975 & 1985 & 1990 & 2000 & 2007 & 2015 & 2019 \\
\hline Bolvadin District & 20,139 & 29,218 & 35,509 & 44,969 & 52,398 & 31352 & 31227 & 32610 \\
Centre & & & & & & & & \\
Derekarabağ Village & 378 & 608 & 739 & 801 & 937 & 891 & 843 & 793 \\
Ortakarabağ Village & 975 & - & - & 469 & 367 & 269 & 206 & 173 \\
Eber (Doğan) Village & 1,322 & 1,525 & 1,594 & 2,496 & 1,377 & 1037 & 700 & 613 \\
\hline
\end{tabular}

Source: Turkish Statistical Institute, 2019 


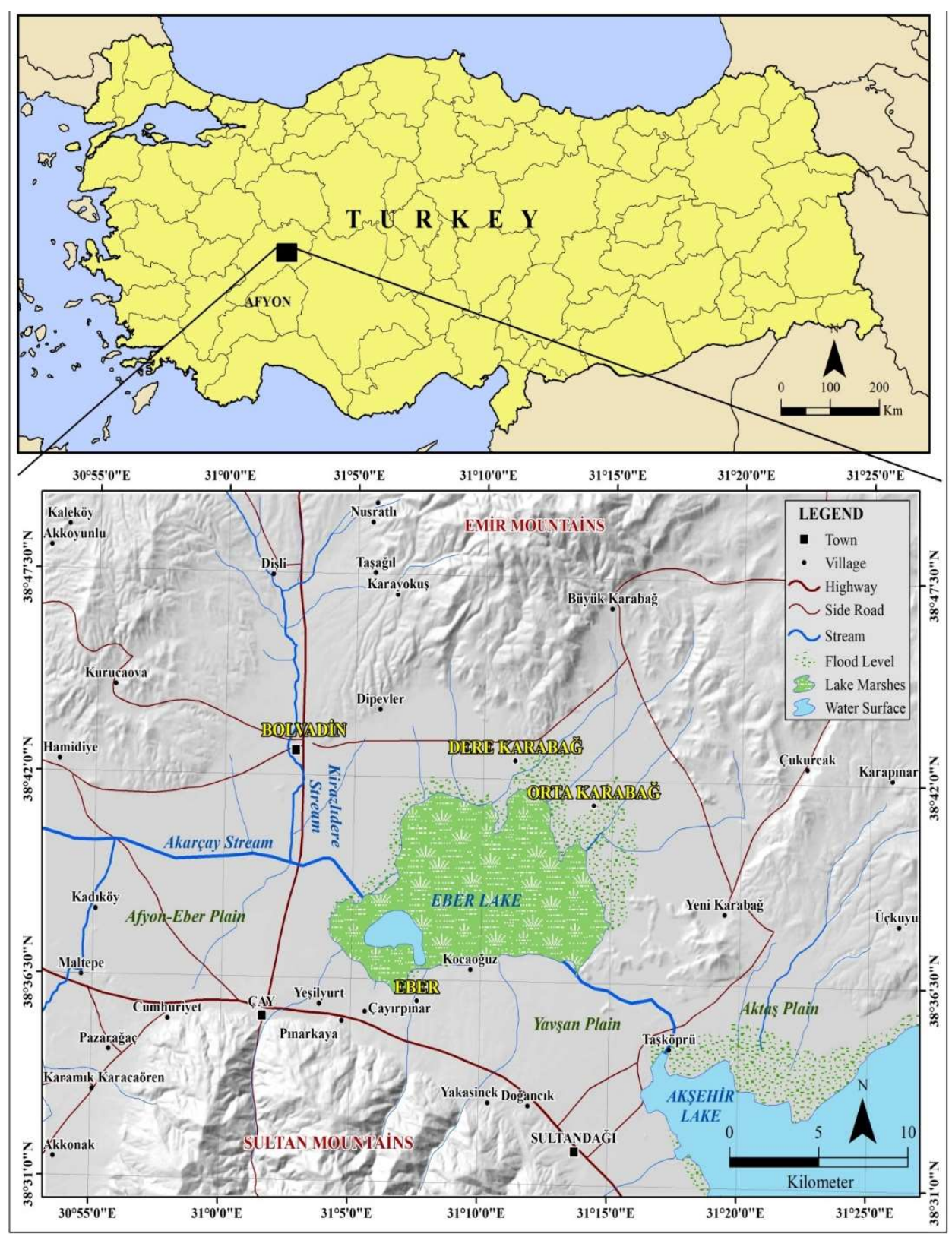

Figure 1. Location map of the research site and the water surface and marshes in the Lake Eber (2019)

The economic structure in Derekaraba $\breve{g}$, Ortakaraba $\breve{g}$ and Eber villages is based on agriculture-animal husbandry, reed-cane craftsmanship and reed-cane production. Within this structure, the reed-cane craftsmanship and the production of reed-cane products are gradually decreasing. Considering the economic structure of Bolvadin district centre, a significant part of the population works in the service and industry sector, while the agricultural sector has lost its importance (Özdemir \& Günay, 2005). 


\section{Cultural Ecology of Reed-Cane Craftsmanship}

\section{Reed-Cane Craftsmanship}

The reed-cane craftsmanship in Lake Eber has an old history and an important place in the local economy and culture. Despite the decreasing interest in recent years, reed-cane craftsmanship is still economically preferred by the local people. Although many aquatic plant species are grown in the lake, common reed (phragmitesaustralis) (Photo 2A), reedmace (typha-typhaceae species), lakeshore bulrush (schonoplectuslacustris) and common cattail (typha-typhaceae species) are cut economically. While cutting activities carried out within the context of the reedcane craftsmanship were done under the local people's initiative in the past years, today they are determined by the $5^{\text {th }}$ Regional Directorate of the Ministry of Agriculture and Forestry. Within the scope of the lake protection measures, the cuttings are made with permissions issued by the $5^{\text {th }}$ Regional Directorate (Photo 1B). This document also determines cutting periods, type of cutting, species allowed to be cut and the amount of cutting allowed.

Within the scope of the permission, common reed is harvested between November and March and reedmace, common cattail and lakeshore bulrush are cut between July and December. Cutting activities start with the preparations made by the lake at sunrise. With the completion of the preparations, the cutting areas are reached with wooden boats with a flat base unique to the region (produced in the district centre of Bolvadin). The cuttings are mainly carried out in the shallow and swampy parts of the lake (Figure 1).

The cutting of all plants is carried out by hand and using a sickle, as specified in the permit and lasts all day long. The reed-cane plants cut in the lake are transported to the shore by boats in bundles. They are then loaded on vehicles called pat-pat (produced by the farmers themselves and used only in the village; they are used only in the village to avoid obligatory expenses such as taxes, insurance) and delivered to houses or merchants. The reed-cane craftsmanship can be done personally, or by casual workers hired by merchants who are engaged in the commerce of these plants and their products. The daily wages are given per bundle and it was 70-80 Kurus (15-17 Euro cents) per bundle in 2018.
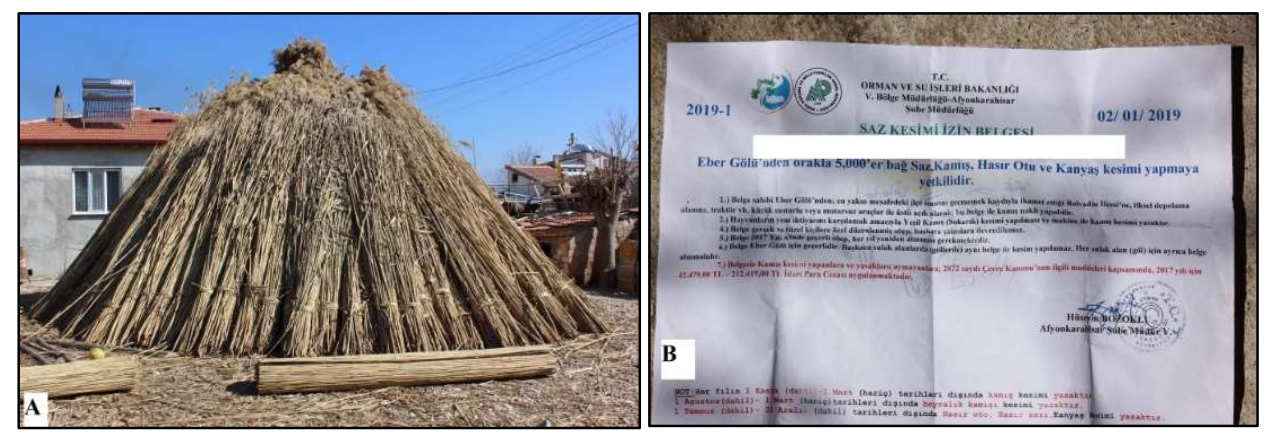

Photo 1. A-A view of common reed bundles, B-Reed cutting permission document. 


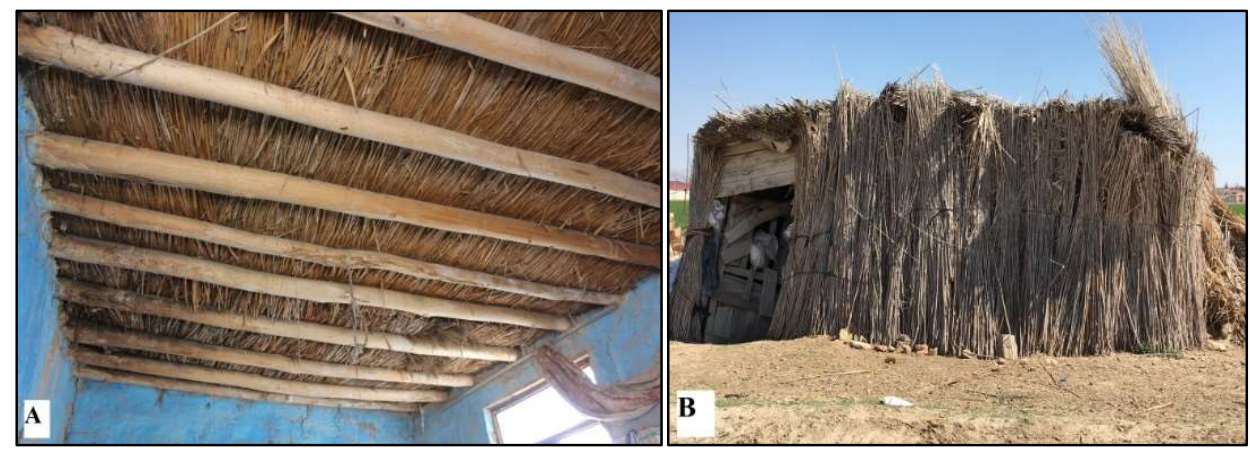

Photo 2. A-Common reed used as roof cover, B-Poultry house made up of common reed

The locals bring the bundles to yheir home and then they are classified according to their intended use. The plants to be used immediately are shipped directly to the production stage, while the rest are stored in an open area. While common reed bundles are transformed into pyramid-shaped piles called Huğla (Photo 1A), other plant decks are stacked on top of each other.

The locals benefit from the plants in various ways both in their daily life and economically. For example, common reed is used as a building material (roof cover, insulation plate, fence, poultry house), reedmace is used in the production of umbrella for tourist facilities and as fuel. All houses built before modern reinforced concrete appeared in the region are covered with reed and clay soil or tiles. Fences used to separate houses or gardens belonging to different people are also made up of reed bundles. In addition, reed is used in the construction of areas such as warehouses, barns and poultry houses and roof covers (Photo 2). The following factors can be influential in such intensive use of reed as a construction material in the region: it is abundant, cheap and easily accessible, easy to process and provides sound insulation.

The export of common reed, which has increased in recent years, has also opened a new door of income to the region. Common reed is exported as roofing material to countries such as the UK, Netherlands, Belgium, Denmark and Germany. High-quality canes are selected, cleaned and cut into pieces of 2-2.2m length, then loaded onto trucks in bundles and transported to Mersin port and from there to the requesting countries. The centre of this export is Derekarabag Village, and it is carried out by four different merchants.

\section{Manufacturing of Reed-Cane Products}

Although plant weaving is performed in all of the settlements included in the sample area, the workshop-type enterprises in Ağılönü neighbourhood (Bolvadin) are the centres of production and trade. In other villages, home-type production is mostly carried out, and the products are marketed through merchants. In the region, plant weaving is performed on horizontal wooden looms, and vertical metal looms. 


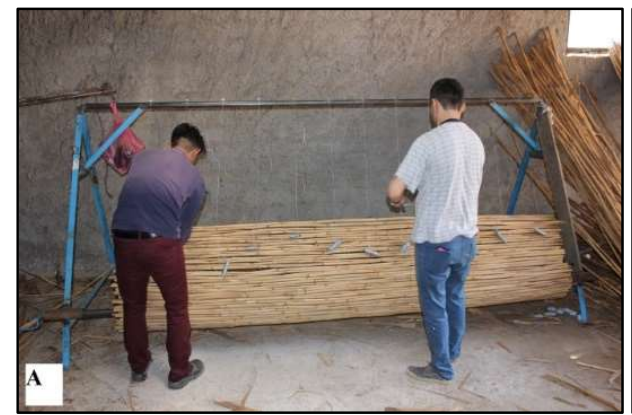

Photo 3. A - The production of a rush mat

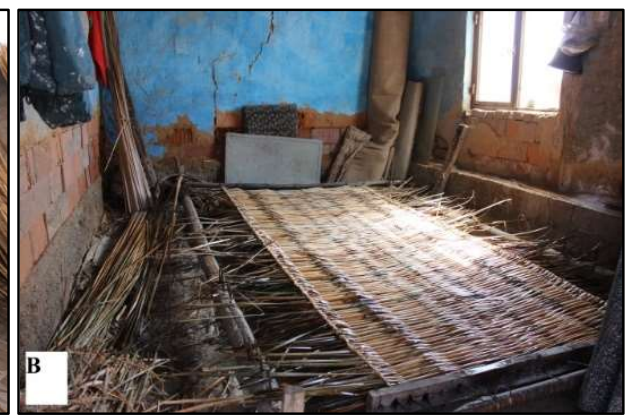

B - Production of a floor mat

On wooden looms, products are generally woven using reedmace and lakeshore bulrush, while on metal looms, products woven using common reed are made. Reed pillow is also used in production in the region.

Although women mostly carry out plant weaving activities, men also work in the production of mats and pillows. Men mainly work in the supply of raw materials and commercial activities. There are also examples where family members work together at every stage of production. Plant weaving was performed in almost every house in Ağllönü (Bolvadin) neighbourhood in the past, but today this number has decreased to 30-40 houses. Again, the number of houses and families manufacturing reed pillows has decreased to 15-20 houses. The same situation is observed in the villages from the area.

In the region, common reed is used in producing roof material, mats, beach umbrellas; reedmace is used to produce pillows and prayer rugs; common cattail is used to produce pillow, and tomb mats and lakeshore bulrush is used to produce floor mats, beach umbrellas, prayer rugs and tomb mats (Photo 3).

The majority of these products are marketed within the country. Indeed, roofing materials, beach umbrella and reed varieties are mainly sold to tourist resorts located on the Mediterranean and Aegean coastal belt; tomb mats in Izmir and its surroundings and reed pillows are marketed to all parts of Turkey. Reed pillows are in great demand, especially in the creation of sitting and resting areas known as oriental corners. In 2018, the price of a reed pillow was 20 TL (4 Euro) and weavings were priced between 10TL (2 Euro) and 50 TL (10 Euro) a piece. However, the demand for these products has decreased considerably. Gülsüm expressed her opinions on the issue as follows:

30-40 years ago there was a lot of demand for weaving and we could make money then.

Now, the trader pays just 10 TL for a mat. I am weaving until noon. During this time I only weave 2-3 mats.

\section{Politic Ecology of Reed-Cane Craftsmanship. Turkey Cellulose and Paper Factories} Inc. (TCPF)

The main political factor affecting reed-cane craftsmanship was the privatization and closing of the TCPF Çay / Afyonkarahisar factory in 2003. The factory, which started its operations in 1979, procured most of the reed-cane plants used as raw 
materials from lakes Eber and Karamık in its vicinity. This provided the people living around Lake Eber with the opportunity to supply raw materials, and reedcane cutting in Lake Eber gained speed. This occupation which had a high financial return, turned into an essential source of income, especially in the 1990s and contributed to the economic strengthening of the region. The increase in economic income has also been effective in preventing rural-urban migration in the region. When the results of the 1990 and 2000 censuses are examined, the effects of reed craftsmanship on the local population are clearly visible (Table 1). During these years, the population living in the area reached its highest level. When asked about the effects of TCPF on the region during the interviews made with local people, the following were registered:

We were making very good money when there was TCPF. We saw a deck of money for the first time there. We used to sell the reeds we cut on a $\mathrm{kg}$ basis and get the money immediately. We used to shop at the bazaar with weekly fees. Traders would look forward to us (Ahmet, Mehmet).

The closure of the factory in 2003 affected the lifestyle of the locals. The reedcane cutting, which contributed significantly to employment, has started to lose its importance since this date. The people whose economic income decreased started to migrate to cities again. In addition, the decrease in cutting activities caused the reed-cane plants not to regenerate themselves, piling up on the lake floor as organic wastes and thus increasing pollution.

\section{Dam-Pond Projects Implemented by SHW}

The water that gives Lake Eber its wetland identity is gradually decreasing in the field. The lake area, which was $124.74 \mathrm{~km}^{2}$ in 1977 , decreased to $66 \mathrm{~km}^{2}$ in 2019 (Atalay, 1977; SHW 183 ${ }^{\text {rd }}$ Branch Directorate of Afyonkarahisar, 2019). The shrinkage rate experienced is over $50 \%$. Answers to support the aforementioned data were also obtained in the interviews conducted with the local people: In the 1970s and 1980s, water was abundant in our youth; almost $60 \%$ of the lake area seen at that time has dried up (Ali, Hasan).

Although there are factors such as temperature-evaporation, precipitation, underground-surface water flows and usage of these waters among the reasons for spatial shrinkage, it is thought that the main determining factor is the decrease in the amount of water entering the lake. This situation is also supported by the flow data from the observation station located on Akarçay at the entrance of Lake Eber. The first amount recorded as $4,460 \mathrm{~m}^{3} / \mathrm{sec}$ at the station, which started data collection in 1999, decreased to $1,064 \mathrm{~m}^{3} / \mathrm{sec}$ in 2014 (General Directorate of State Hydraulic Works, 2014). The main reason for this decrease are the dams and ponds built on the creeks and streams feeding the lake, especially Akarçay. Dampond projects implemented by SHW have prevented or optionally restricted the flow of rivers to the lake. In 2019, the number of dams and ponds in service was over 20, and there are facilities in the process of construction (SHW $183^{\text {rd }}$ Branch Directorate of Afyonkarahisar, 2019). 
The lack of water in the lake negatively affects the growth of reed and cane. Plants that cannot meet their water needs cannot achieve the expected growth. The drying out in shallow areas especially causes the plants here to die. This situation negatively affects the availability of plants suitable for cutting, the quality of cutting and therefore the reed-cane craftsmanship. Accordingly, the number of quality plants required for reed-cane products and export is decreasing day by day. Local people are also aware of this situation and stated that:

The lake needs water; without water the Lake Eber will dry. Drying of the lake means that we also dry up. When there is no water in the lake, reed-cane plants do not grow. If these are not grown, the livelihoods of the people living in this environment will be dried out. Children of people who made their living from reed-cane craftsmanship and reed-cane production migrated to cities. The lake lost the power to feed Bolvadin and the surrounding villages. You saw the situation; in this neighbourhood (Ağllönü / Bolvadin), everyone used to be involved in reed-cane production activities and weaving, but now very few families continue this business. We want water for the lake. Water does not come, because a dam or pond has been built in every stream and creek that flows into the lake. If it rains, the water stops in the lake, if it does not rain, the existing water dries up. (Ali, Hasan, Ömer, Osman).

They put the main emphasis on the water, which is the main element in the lake ecosystem.

\section{Domestic, Industrial, Geothermal Wastes and Agricultural Activities}

Another factor affecting reed-cane craftsmanship is the pollution in the lake. Akarçay, which is the main river feeding the lake, is also the most critical pollutant. As a matter of fact, the waste waters belonging to settlements such as Sinanpaşa, Afyonkarahisar, İhsaniye, İsçehisar, Çobanlar, Bolvadin, Şuhut, Karaadilli and Çay in the Akarçay basin are discharged to Akarçay (Özdemir \& Uçar, 2006). Among the pollutants are domestic, industrial, geothermal (discharge of used geothermal water to Akarçay) and agricultural wastes.

While domestic wastes belonging to the settlements were directly discharged to Akarçay in the past, today, they are treated in wastewater treatment facilities and then discharged. However, treatment facilities are not yet in a position to cover the entire area. In this regard, wastewater treatment facilities are actively working in Düzağaç, Afyonkarahisar Centre (advanced biological), Çobanlar, Şuhut, Karaadilli and Çay (Afyonkarahisar Governorship Provincial Directorate of Environment and Urbanization). The wastewater of the remaining settlements is directly discharged into the Akarçay basin. The same holds for industrial wastes. Industrial wastes generated in Afyonkarahisar Organized Industrial Zone, which is the largest industrial production centre in the region, are transported to Afyonkarahisar Central Wastewater Treatment Plant through a sewage system (Afyonkarahisar Governorship Provincial Directorate of Environment and Urbanization). However, there are some industrial facilities that are not included in this system and illegally discharge their wastes to Akarçay. The wastes 
belonging to these facilities are discharged to Akarçay without any treatment or without adequate treatment (Photo 4B).

There are 3 different geothermal fields in Akarçay basin. These are ÖmerGecek (Center / Afyonkarahisar) hot spring, Gazlıgöl (İhsaniye / Afyonkarahisar) hot spring and Heybeli (Bolvadin / Afyonkarahisar) hot spring. While there are many facilities for thermal tourism in the hot springs, there are also heating centres in Ömer-Gecek and Gazlıöl. However, geothermal resource management and use are not at the desired level. In most of the touristic facilities, thermal water is used thoughtlessly and is discharged into Akarçay basin without adequate treatment. This also applies to thermal waters used in heating centres (Photo 4A). Thermal water discharged with high temperature, sodium, chloride, dissolved matter, and low dissolved oxygen contents is classified as $4^{\text {th }}$ class (heavily contaminated) (Özdemir \& Uçar, 2006).

Agricultural production is also intensely carried out in the plains surrounding Lake Eber. Wheat, barley, sugar beet, poppy, potato, fodder crops (silage corn, alfalfa, vetch), various vegetables and fruits are grown on these lands. Large amounts of fertilizers and pesticides are used during their cultivation. These substances mix into the soil and, in time, with underground and surface waters and cause pollution. Supplying the water needed for irrigation from Akarçay and its branches and drilling wells causes the resulting pollution to turn into a cycle. This cycle reaches Lake Eber again via Akarçay. Fertilizer and pesticide residues reaching the lake cause eutrophication as well as pollution. In the fieldworks conducted in July 2018, it was found that algae were concentrated on the lake floor, and water flowers such as water lilies were concentrated on the surface.

Another effect of agricultural activities occurs with irrigation in the summer months. The water needed especially during the cultivation of products with high water demand such as sugar beet, silage corn, potatoes and alfalfa puts a great pressure on the resources in the Akarçay basin. The water needed is supplied from irrigation systems integrated with dams and ponds, surface waters and boreholes. The use of water covering the dry period also greatly restricts the amount of water that needs to reach Lake Eber.
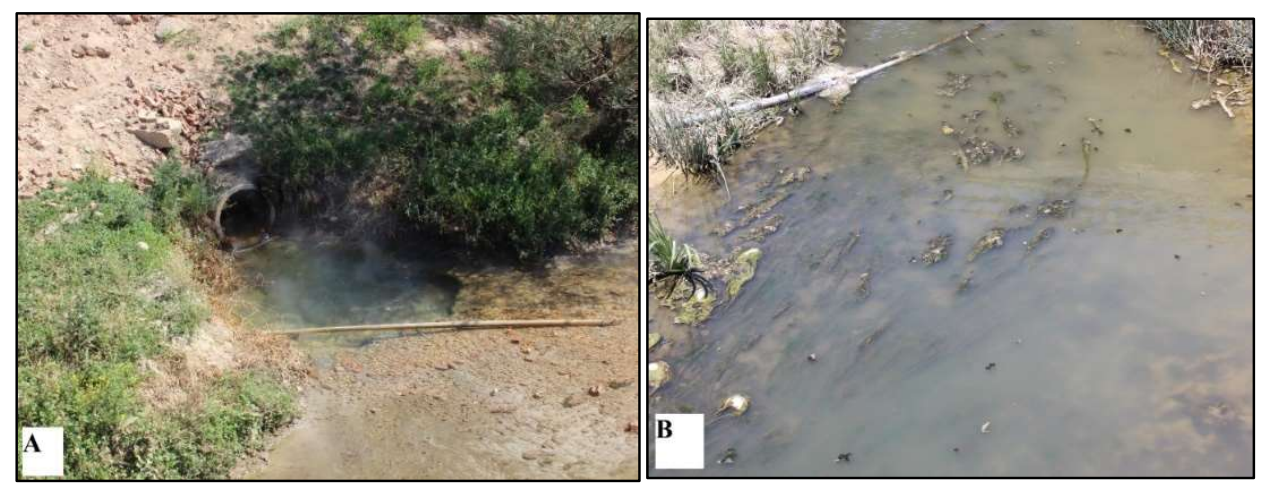

Photo 4. A-Thermal waters discharged to Akaraçay, B- View form Akarçay 
In addition, the increasing need for irrigation has led to the construction of irrigation systems with more dams and ponds. Lake Eber, whose waters are getting lesser nowadays, also has a clean water problem due to the reasons mentioned above. The amount of water reaching the lake is both low and polluted. This situation negatively affects the ecology of the lake and reed-cane plants. The reed-cane plants that do not have access to sufficient clean water cannot provide the required growth and development for cutting and production.

Lake Eber is very polluted. In the 1980s, we would take the water from the lake to use it for our tea, soup and food. In that period, when we looked at the water from the boat, we could see it to the bottom. Now we can't see it from pollution. Wastes from the industrial areas in this region always come to the lake. There is very little water coming to the lake anyway and it comes polluted. As such, reed-cane plants do not grow well either. People also stop going to the lake when the plants aren't good. Not only the plants but also fish died in the lake. Even the number of migratory birds coming to the lake started to decline (Ali, Hasan, Ömer).

Thus, they emphasized the extent of pollution.

\section{Discussions}

The reed-cane craftsmanship and the production of reed-cane products have been an ongoing economic activity for many years in Lake Eber and its vicinity. The plants cut from the lake and the products made from these plants have become synonymous with the research area that they have made it attain a unique place within the socio-cultural structure. The traces of this can be seen in some houses in the area. In this context, the roof covers of the houses built before reinforced concrete houses are covered with reed. Again, it is seen that the use of reed continues in the construction of some buildings such as barn, coop, warehouse and roof covers. The use of products such as rush mat varieties, prayer rugs and reed pillows still continues in daily life.

The reed-cane craftsmanship and the production of reed-cane products under the influence of Lake Eber are affected by some local and national processes and political factors. Opening and closing of TCPF Afyonkarahisar / Çay factory, SHW activities, agricultural and industrial activities and the use of geothermal resources in tourism have been factors affecting the area at different scales. These factors have led to an acceleration of degradation in the lake ecosystem. The change in the ecological structure has been reflected in the reed-cane craftsmanship, the production of reed-cane products, and therefore on locals' lifestyles.

While some of the processes and factors mentioned are the activities of the local people, the majority of them are the result of external decisions and interventions. The effects of the local people on the lake are mostly induced through agricultural activities. The supply of water needed during the cultivation of agricultural products from aboveground and underground sources in the 
Akarçay basin restricted the water flow to the lake and caused a water shortage in the lake. Again, the mixing of the drug and fertilizer residues used caused pollution and eutrophication in the lake.

External interventions that developed depending on the political decisions caused more destructive effects on reed-cane craftsmanship and the lake. While reed-cane craftsmanship was an important source of income when TCPF Afyonkarahisar/Çay Factory was open between 1979 and 2003, it has lost its importance with the privatization and then closure of the factory. On the other hand, with the dam-pond projects implemented by SHW, the natural regime of the water resources in the Akarçay basin was modified. This has caused a decrease in the amount of water reaching the lake. Again, domestic, industrial and geothermal wastes reaching the lake through Akarçay and its tributaries caused pollution. These adversities affecting the ecological structure of the lake also affected the growing conditions of reed-cane plants. The reed-cane plants that do not have access to sufficient clean water cannot achieve the sizes and growth sought for cutting and production.

These adversities, which lead to significant financial losses, also have sociocultural effects. As a matter of fact, the interaction of the local people with the lake, which they see as a part of themselves, is gradually weakening. This cuts people from their lands and forces them to migrate. The reed-cane products made in the region are also decreasing parallel to the decrease in the number of their producers. Plant weaving, which has had a rooted and important place in handicrafts, and reed pillow production are not found to be appealing by young people. These handicrafts, whose future is uncertain due to low economic income, difficult working conditions and environmental problems in the lake, are no longer popular in the region. If the process continues in this way, it seems that both plant weaving and reed pillow production are doomed to be forgotten and lost. In addition to all these, while the cutting activities carried out every year contribute to the growth of reed-cane plants in a more lush and healthy way, it is thought that decreasing cutting activities will negatively affect this situation.

It was observed that even if they do not live in the field, the wetland of Eber Lake is shaped by the institutions and organizations that have the authority to make and implement decisions more than the people living there. The absence of a systematic wetland management plan against threats affecting the lake ecology and local lifestyles has also contributed to this. Even though Eber Lake was registered as a $1^{\text {st }}$ degree natural site on 22 June1992, it was exposed to unsustainable agricultural practices, affecting the water regime and producing various wastes. Although some positive developments (such as the establishment of wastewater treatment plants) have been experienced in recent years, the degradation in lake ecology could not be prevented. For this reason, Lake Eber was registered as a sensitive area to be protected on 03 November 2020. With this status, it is expected that there will be various restrictions for the protection and use in Lake Eber.

With the Ramsar Convention, it is emphasized that wetlands are important not only for the bird, fish and plant species living in these areas but also for the locals 
living around them (Ar1, 2003). During the use of the facilities and natural resources, it is necessary to establish a good balance of protection and use. The easiest way to achieve this is to create a management plan in wetlands following the principles of the Ramsar Convention. There is a misperception that the Ramsar Convention is merely an attempt to protect wetlands of international importance. However, the Convention encourages each country to classify, protect and manage wetlands within their borders as wetlands of international, national, or local importance (Arı, 2019). In this context, Eber Lake needs a management plan in accordance with the wise use principles of the Ramsar Convention. While external interventions primarily help prevent the deterioration in lake ecology, the outcomes affect local people. As a matter of fact, the growing conditions of the reed plants are getting worse, and the growing areas are narrowing due to the lack of water, pollution and eutrophication. This situation restricts the reed cutting activities and causes socio-economic losses for the local people. Cutting activities are carried out within the determined quotas and permissions. Although this practice seems to be sustainable, it just tries to alleviate the pressure on reed plants.

A fire broke out in the marshy areas on 08 December 2020, shortly after the lake was declared as a sensitive area to be protected. The fire caused damage to various plant and animal species, especially reed plants. This fire coincided with one of the cutting periods and affected the local people's cutting activities adversely. Unfortunately, this reveals that Lake Eber could not be protected adequately. Ecological resources and locals who should benefit from these resources suffer these outcomes the most.

\section{Conclusions}

In order to protect the ecological potential of the lake and to transfer the lifestyle created by the locals, and ensuring that future generations will use the lake, it is necessary to improve the sustainable use conditions in the field. In this context, the following suggestions are presented for the improvement of the ecological structure of the lake and the development of reed plants and reed work:

- In order to ensure water circulation in the lake, clean water should be provided from suitable water sources.

- Measures and practices should be developed to reduce the pollutants reaching the lake. In this context, wastewater treatment facilities should be established in settlements located on the Akarçay basin and in places where there is no wastewater treatment facility. Illegally discharged wastes caused by industrial activities must be prevented. Moreover, it should be ensured that the wastes of thermal facilities are treated and discharged after cooling.

- Agricultural products that consume less water should be encouraged instead of products that consume a lot of water, such as sugar beet, silage corn, potatoes and alfalfa in the lands around the lake. In this way, excessive use of surface and underground water resources should be prevented. 
- Unnecessary use of pesticides and fertilizers in agricultural activities should be prevented.

- Usage and marketing activities for reed-cane plants and reed-cane products should be re-evaluated. In this context, the isolation properties of plants should be brought to the foreground, and their usability as building materials should be emphasized in the marketing activities directed to the countries such as the Netherlands, Belgium, Denmark and Germany.

- It should be ensured that the production of reed-cane products is reorganized according to today's needs. In this context, products such as prayer rugs, rush mats and reed pillows for daily use should be promoted and marketed in the city centre, especially in thermal tourism centres.

- For the sustainable use of Lake Eber and reed-cane plants, the cooperation of local and national stakeholders should be ensured, and a management plan should be established following the principles of the Ramsar Convention.

\section{References}

Adaman, F., Hakyemez, S. and Özkaynak, B. (2009), "The political ecology of a Ramsar Site conservation failure: the case of Burdur Lake, Turkey", Environment and Planning C: Government and Policy, vol. 27 no. 5, p. 783-800.

Arı, Y. (2003), "Cultural ecology of Lake Manyas: adaptation and change in historical perspective", Turkish Geographical Review, no. 40, p. 75-97.

Arı, Y. (2006), "The Ramsar Convention on wetlands: a critical review", Eastern Geographical Review, vol. 11, no. 15, p. 275-302.

Arı, Y. (2019), "Nature conservation at Gönen Creek Delta wetlands (Balikesir): water, culture and life", International Journal of Geography and Geography Education, no. 40 p. 151-171.

Arı, Y. and Derinöz, B. (2011), "How not to manage a wetland? The case of Lake Marmara (Manisa) with a cultural ecological perspective", Turkish Journal of Geographical Sciences, vol. 9 no. 1, p. 41-60.

Astelarra, S., De La Cal, V. and Domínguez, D. (2017), "Conflicts in the Ramsar Sites of Argentina: contributions to the political ecology of wetlands", Letras Verdes. Revista Latinoamericana de Estudios Socioambientales, no. 22, p. 228-247.

Atalay, İ. (1977), Structural, Geomorphological and Soil Erosion Study of Sultandağlar and Akșehir and Eber Lakes Basins, Atatürk University Publications No.500, Erzurum.

Bahadır, M. (2012), "Integrated coast area management of lakes Eber and Akșehir", Turkish Journal of Geographical Sciences, vol. 10, no. 1, p. 63-90.

Barbraud, C. and Mathevet, R. (2020), "Is commercial reed harvesting compatible with breeding purple herons Ardea purpurea in the Camargue, southern France?", Environmental Conservation, vol. 27, no. 4, p. 334-340.

Bayar, M. (1996), History of Bolvadin, One of the Oldest Cities of Anatolia (Volume 1), Doğus, Printing, Ankara. 
Büyüköztürk, S,., Çakmak, E.K., Akgün, Ö.E., Karadeniz, Ș. and Demirel, F. (2012), Scientific Research Methods (twelfth edition), Pegem Academy, Ankara.

Campion, B.B. and Owusu-Boateng, G. (2013), "The political ecology of wetlands in Kumasi", International Journal of Environment and Bioenergy, vol. 7, no. 2, p. 108-128.

Deak, B., Valko, O., Török, P., Kelemen, A., Toth, K., Miglecz, T. and Tothmeresz, B. (2015), "Reed cut, habitat diversity and productivity in wetlands", Ecological Complexity, vol. 22, p. 121-125.

Decleer, K. (1990), "Experimental cutting of reedmarsh vegetation and its influence on the spider (Araneae) fauna in the blankaart nature reserve, Belgium", Biological Conservation, vol. 52, no. 3, p. 161-185.

Erdem, O. (1995), Turkey's Bird Sanctuary, Ministry of Environment, Ankara.

Eroğlu, A. (2009), "A social antrophologic research on Karabağlilar living in the Bolvadin area and Ortakarabağ village" (Master Thesis), Ankara University, Ankara.

Evered, K.T. (2012), "Political ecologies of Turkey's wetlands and lake Burdur: the case of Demirel and the duck", The Arab World Geographer, vol. 15, no. 1, p. 45-71.

Geertz, C. (1983), Local knowledge: further essays in interpretive anthropology, Basic Books, New York.

General Directorate of State Hydraulic Works (SHW) $183^{\text {rd }}$ Branch Directorate of Afyonkarahisar (2019), Dams and Ponds in Operation, 17 July 2019, https://bolge18.dsi.gov.tr/Sayfa/Detay/1030.

General Directorate of State Hydraulic Works, Turkey (2014), Current Observation Annuals, 2 August 2020, https://www.dsi.gov.tr/Sayfa/Detay/744.

Graveland, J. (1999), "Effects of reed cutting on density and breeding success of Reed Warbler Acrocephalus scirpacaeus and Sedge Warbler A. schoenobaenus", Journal of Avian Biology, no. 30, p. 469-482.

Güney, E. (1995), "Environmental problems of wetlands in Turkey", Turkish Geographical Review, no. 30, p. 41-52.

Hancock, B. (1998), An Introduction to Qualitative Research, Trent Focus Group, Nottingham

Hasbek, M. (2018), "Cultural and Political Ecology of Lake Karamik (Afyonkarahisar)" (Master Thesis) Balıkesir University, Balıkesir.

Hasbek, M. and Arı, Y. (2018), "They will not give us our Lake: Cultural and politıcal ecology of Lake Karamik (Afyonkarahisar)", Eastern Geographical Review, vol. 23 no. 40, p. 37-60.

Huque, S., Pattanaik, S. and Parthasarathy, D. (2020), "Cityscape transformation and the temporal metamorphosis of East Kolkata Wetlands: A political ecology perspective", Sociological Bulletin, vol. 69 no.1, p. 95-112.

Kalkan, A. and Gönül, E. (2018), "The conversıon of giant reed (Arundo Donax L.) knitting into touristic product in lower Meander Basın", The Journal of International Social Research, vol. 11, no. 57, p. 297-310.

Kandır, H. (2018), "An elaborate red: Lake Eber", Lake District Economy and Culture Magazine Journal Detail, vol. 6, no. 69, p. 49-56. 
King, B., Shinn, J.E., Yurco, K., Young, K.R. and Crews Meyer, K.A. (2019), "Political ecologies of dynamic wetlands: Hydrosocial waterscapes in the Okavango Delta", The Professional Geographer, vol. 71, no. 1, p. 29-38.

Köle, M.M., Ataol, M. and Erkal, T. (2016), Spatial changes of Eber and Akşehir lakes between 1990 and 2016, TÜCAUM International Geography Symposium 13-14 October 2016, Ankara, p. 859-872.

Komulainen, M., Simi, P., Hagelberg, E., Ikonen, I., Lyytinen, S. and Salmela, P. (2008), Reed Energy: Possibilities of Using the Common Reed for Energy Generation in Southern Finland, Saarijärven Offset Oy, Helsinki.

Korkmaz, H. and Gürbüz, M. (2008), "Cultural ecology of Lake Amik", International Journal of Geography and Geography Education, no. 17, p. 1-26

Korukoğlu, A., Gündüz, S,. and Güneyli, A. (2017), "Evaluation of Opinions Related to Endangered Neolopolis Wetland in North Cyprus", Eurasia Journal of Mathematics Science and Technology Education, vol. 13 no. 6, p. 2215- 2233.

Ministry of Environment and Urbanisation Turkey (2018), Afyonkarahisar Registered Natural Sites and Natural Assets List, 10 August 2020, shorturl.at/yY238. Mitsch, W.J. and Gosselink, J.G. (2015), Wetlands, (third edition), Wiley, New York. Mmopelwa, G. (2005), "Economic and financial analysis of harvesting and utilization of river reed in the Okavango Delta, Botswana", Journal of Environmental Management, vol. 79, no. 4, p. 329-355.

Nagabhatla, N. and Sellamuttu, S.S. (2008), "Political Ecology of Wetland Management: the post aquaculture demolition case of Lake Kolleru in India", Revista Geográfica Acadêmica, vol. 2 no. 1, p. 10-19.

Özdemir M.A. and Günay, M. (2005), "The role of the geographıc conditions in the development of the city Bolvadin", Afyon Kocatepe University Journal of Social Sciences, vol. 7, no. 2, p. 129-157.

Özdemir, M.A. and Uçar, H. (2006), "Water pollution in urban ecosystem of Afyonkarahisar", Afyon Kocatepe University Journal of Social Sciences, vol. 8, no. 2, p. 123-158.

Özeșmi, U. (1999), "Ecology and politics of rehabilitation: Mogan Lake wetland ecosystem, Ankara, Turkey" in W. Streever (ed.) An International Perspective on Wetland Rehabilitation, p. 181-187, Springer, Dordrecht.

Poulin, B. and Lefebvre, G. (2002), "Effect of winter cutting on the passerine breeding assemblage in French Mediterranean reedbeds", Biodiversity $E^{\circ}$ Conservation, no. 11, p. 1567-1581.

Poulin, B., Lefebvre, G., Allard, S. and Mathevet R. (2009), "Reed harvest and summer drawdown enhance bittern habitat in the Camargue", Biological Conservation, vol. 142, no. 3, p. 689-695.

Schmidt, M.H., Lefebvre, G., Poulin, B. and Tscharntke, T. (2005), "Reed cutting affects arthropod communities, potentially reducing food for passerine birds", Biological Conservation, vol. 121, no. 2, p. 157-166.

Sönmez, M.E., and Somuncu, M. (2016), "Evaluation of spatial change in the Sultan Marshes in terms of sustainability", Turkish Geographical Review, no. 10, p. 1-10. 
Trnka, A., Peterková, V. and Prokop, P.B. (2014), "Management of reedbeds: mosaic reed cutting does not affect prey abundance and nest predation rate of reed passerine birds", Wetlands Ecology and Management, no. 22, p. 227-234.

Türktaș, Z. (2016), "Wicker weaving in Beyșehir Lake and around", Kalemiși, vol. 7, no. 4, p. 19-38.

Türktaș, Z. (2020), Herbal Weaving in the Lakes District, Gece Kitaplığı, Ankara.

Van Der Sluis, T., Poppens, R., Kraisvitnii, P., Rii, O., Lesschen, J.P., Galytska, M. and Elbersen, W. (2013), Reed harvesting from wetlands for bioenergy, Alterra Wageningen UR, Wageningen.

Wilson, E.B. (1952), An Introduction to Scientific Research, McGraw-Hill, New York.

Yarar, M. and Magnin, G. (1997), Turkey's Important Bird Areas, Wildlife Conservation Association Publications, İstanbul.

Yazıcı, H. and Şahin, İ.F. (1999), "Geographical observation on Demiryurt (Tödürge-Sivas) swamp land and it surrounding", Turkish Geographical Review, no. 34, p. 19-30.

Yeniyurt, C., Hemmami, M., Çă̆ırankaya, S. and Koopmanschap E. (2011), Wetlands Ramsar Site Management Plan in Turkey's Assessment Report, Nature Association, Ankara.

Yiğitbașoğlu, H. (1995), "Seyfe Lake ecosystem", Journal of Turkey Geography Research and Application Center, no. 4, p. 147-169. 